http://jmscr.igmpublication.org/home/ ISSN (e)-2347-176x ISSN (p) 2455-0450

crossref DOI: https://dx.doi.org/10.18535/jmscr/v7i10.29

Journal Of Medical Science And Clinical Research

\title{
Seroprevalence of Hepatitis A Virus infection in healthy adults attending a tertiary care centre in central Kerala- A cross-sectional study
}

\author{
Authors \\ Dr Meghana Venunath ${ }^{1}$, Dr Jasmine Kulapurath Abdul Kader ${ }^{2 *}$, Dr Reena John ${ }^{3}$, \\ Dr Prithi Nair ${ }^{4}$ \\ Department of Microbiology, Government Medical College, Thrissur, Kerala, India Pin code: 680596 \\ *Corresponding Author \\ Dr Jasmine Kulapurath Abdul Kader \\ Department of Microbiology, Government Medical College, Thrissur, Kerala, India Pin code: 680596
}

\begin{abstract}
Background and Objectives: Hepatitis $A$ is the most common form of viral hepatitis. Though it does not cause chronic disease, it can cause significant economic and social consequences in the community. The most important risk factors associated with the viral infection are unsafe water, poor personal hygiene and inadequate sanitation. It is symptomatic in only 4-16\% of the infected children compared to 75-95\% of the adults. As socioeconomic status and access to safe drinking water are increasing, recently an epidemiological transition has been observed about the HAV infections in India. There is a decline in HAV infection rate and clinical disease in children and increase in the number of susceptible adolescents and adults. This is suggestive of an area with intermediate endemicity in contrast to being a hyper endemic area as thought before. This study aims to find out the seroprevalence of anti Hepatitis A virus IgG antibodies in healthy adults in Central Kerala using ELISA technique.

Materials and Methods: This Cross sectional study was conducted in asymptomatic healthy adults including voluntary blood donors, antenatal women presenting to Government Medical College Hospital, Thrissur, Kerala and the medical students of the same college from January 2016-December 2016. Serum samples obtained from 270 subjects were subjected to screening for Anti HAV IgG antibodies using commercially available Enzyme linked Immunosorbent Assay (ELISA) kit.

Results: Out of 270 subjects tested, 41(15.2\%) were positive for IgG anti HAV antibodies.

Conclusion: The present study confirms the declining seroprevalence rates for IgG antiHAV antibodies in the general population. Further larger seroprevalence studies have to be carried out especially among children to assess the need of introduction of Hepatitis A vaccination under universal immunization programme.
\end{abstract}

Keywords: Hepatitis A virus; IgG Anti-Hepatitis A virus antibodies; ELISA; Seroprevalence; epidemiological transition; vaccination.

\section{Introduction}

Hepatitis A, the most common form of viral hepatitis is caused by a RNA virus of the family picornaviridae, for which humans are the only natural host. ${ }^{1}$ It is one of the common causes of food borne infections worldwide, occurring sporadically and in epidemics. Though it does not cause chronic disease like hepatitis $B$ virus or hepatitis $C$ virus, it can cause significant economic and social 
consequences in the community. It may take weeks or months for the affected person to return to normal life.

The most important risk factors associated with the viral infection are unsafe water, poor personal hygiene and inadequate sanitation. The virus is shed in the feces of persons with both asymptomatic and symptomatic infection. $^{2}$

Hepatitis A virus (HAV) is food borne and waterborne, and is stable in the environment for at least 1 month. ${ }^{1,3}$ Rare cases of blood-borne transmission, especially for hemophiliacs (injection of factor VIII), have also been reported. ${ }^{4}$ A source for infection cannot be identified for $40 \%$ to $50 \%$ of reported cases. ${ }^{5}$ Hepatitis A can vary from an asymptomatic infection to a fulminant fatal disease, age being the major factor that influences its clinical course. It is symptomatic in only $4-16 \%$ of children compared with $75-95 \%$ of adults. ${ }^{6}$ It is clinically indistinguishable from other causes of acute viral hepatitis. Specific diagnosis is made by the presence of anti Hepatitis A virus IgM and IgG antibodies in the blood. ${ }^{2}$ IgG anti HAV appears early in the course of the infection and remains detectable throughout the person's lifetime. ${ }^{7}$

The mainstay of management is supportive care. ${ }^{8}$ Several vaccines for hepatitis A are available internationally. Inactivated Hepatitis A vaccine is in widespread use. It is highly immunogenic with good safety profile. ${ }^{9,10}$ Live attenuated vaccines developed however were less immunogenic. ${ }^{11}$

Degree of endemicity of hepatitis A is closely related to the prevailing sanitary conditions, socioeconomic level and other development indicators. In highly endemic areas like Asia, Africa and the Middle East, the seroprevalence of Anti Hepatitis A virus IgG antibodies reaches $90 \%$ in adults and most children are infected by 10 years of age. ${ }^{6}$ As socioeconomic status and access to safe drinking water are increasing, an epidemiological transition from hyper endemicity to intermediate endemicity has been observed recently in India. There is a decline in HAV infection and clinical disease in children and increase in the number of susceptible adolescents and adults at risk of clinical disease. $^{12}$ There is a possibility of hepatitis A outbreaks in near future. This is mainly because the population belonging to lower socio-economic status continues to be hyperendemic, excreting HAV in large quantities whereas a substantial pool of anti-HAV negative adolescents and adults is now present among the higher socio-economic class. ${ }^{13}$ The past outbreaks of hepatitis A in young adults in Kerala- Koothattukulam (1998) ${ }^{14}$, Kottayam $(2004)^{15}$, Kollam (2013) ${ }^{16}$ are suggestive of a region with intermediate HAV endemicity. Rapid improvement of hygienic and socioeconomic conditions in the state might have resulted in a decline of natural childhood infections. Also, there has been a rapid rise in the migrant population in Kerala. These findings reiterate the fact that huge outbreaks of hepatitis A have to be expected in the state in coming years. ${ }^{16}$

Only few studies are published on the seroprevalence of hepatitis A in Kerala. This study aims at finding the seroprevalence of Hepatitis A in healthy adults in Government Medical College Hospital, Thrissur.

\section{Materials and Methods}

Study was conducted in healthy adults including medical students in Government Medical College, Thrissur over a period of one year from January 2016-December 2016. This medical College, located in central Kerala, is a leading tertiary care centre delivering health care to patients mainly from Thrissur district and also Palakkad, Ernakulam and Malappuram districts of Kerala and neighboring areas of Tamil Nadu. Study population included 270 subjects who were Voluntary blood donors, Antenatal women, Medical and paramedical students in the age group 18-45 years. Samples were taken in equal proportion from all the three study groups. Patients with history of HIV infection, Hepatitis B and Hepatitis C virus infections were excluded from the study. The blood samples collected were also screened for Hepatitis B, Hepatitis $\mathrm{C}$ and HIV infection after obtaining a written informed consent. A questionnaire was provided to each of the subject to obtain details 
about their socioeconomic status, lifestyle, habits, relevant medical history including vaccination of hepatitis A, past hepatitis A outbreaks in locality and awareness about hepatitis A infection. Serum samples were subjected to ELISA using bioneovan HAV-IgG ELISA kit for detection of anti-HAV IgG antibodies. The statistical analysis was performed with the help of IBM SPSS statistics 20 software.

\section{Results}

Out of 270 study subjects, $139(51 \%)$ were females and $131(49 \%)$ were males. $41(15 \%)$ tested positive for anti HAV IgG antibodies and 139 (85\%) were seronegative for IgG antiHAV antibodies. (Fig 3.1). 175 subjects $(64.8 \%)$ were young adults belonging to the age group 18-25 and 95 (35.2\%) belonged to age group 26- 45 years. The prevalence of $\mathrm{IgG}$ anti HAV antibodies was maximum for age group 40-45 years $(20 \%)$. According to modified Kuppuswamy scale, of the 270 subjects, 9 subjects belonged to lower socioeconomic class, 57 subjects were from lower middle class, 199 subjects belonged to middle class and 5 subjects were from upper socioeconomic class. The prevalence was maximum in middle class $(16.01 \%)$. The high prevalence in middle class when compared to other classes was found to be statistically significant. $(\mathrm{p}<0.05) .210$ subjects $(78 \%)$ obtained their drinking water from shallow well, 17 subjects $(6 \%)$ used tube well and 43 subjects $(16 \%)$ depended on municipal water supply for drinking water. When interviewed about method of water purification employed prior to drinking 69 subjects confessed of using any method of water purification prior to drinking, 175 subjects used drinking water after boiling and 26 subjects used water filters. Highest seroprevalence was found in persons who do not use a method of water purification (18.8\%). However this association is statistically insignificant. When asked about general awareness of viral hepatitis, 133 (49.3\%) were unaware about the mode of spread of hepatitis A and its prevention.

\section{Discussion}

The present study was aimed at determining the seroprevalence of $\mathrm{IgG}$ anti-HAV antibodies in healthy adults including medical students in Government Medical College, Thrissur. In this study, 90 subjects were voluntary blood donors (33.3\%), 90 were antenatal women $(33.3 \%)$ and 90 were medical students $>18$ years $(33.3 \%)$.

Out of 270 subjects, 41(15.2\%) were positive for IgG anti HAV antibodies. This is in consistent with the seroprevalence data published in Kerala. The lowest seroprevalence rates in India have been consistently reported from Kerala ${ }^{17}$. The study by Mathews et al ${ }^{18}$ showed a seroprevalence rate of $4.5 \%$ in children under 5 years of age. Mall et $a l^{12}$ reported a varying seroprevalence rate from $26.2 \%$ to $85.3 \%$ in various cities of India with a significantly low rate in Kochi city of Kerala especially in under 5 age group $(10.3 \%)$ than in other states of India.

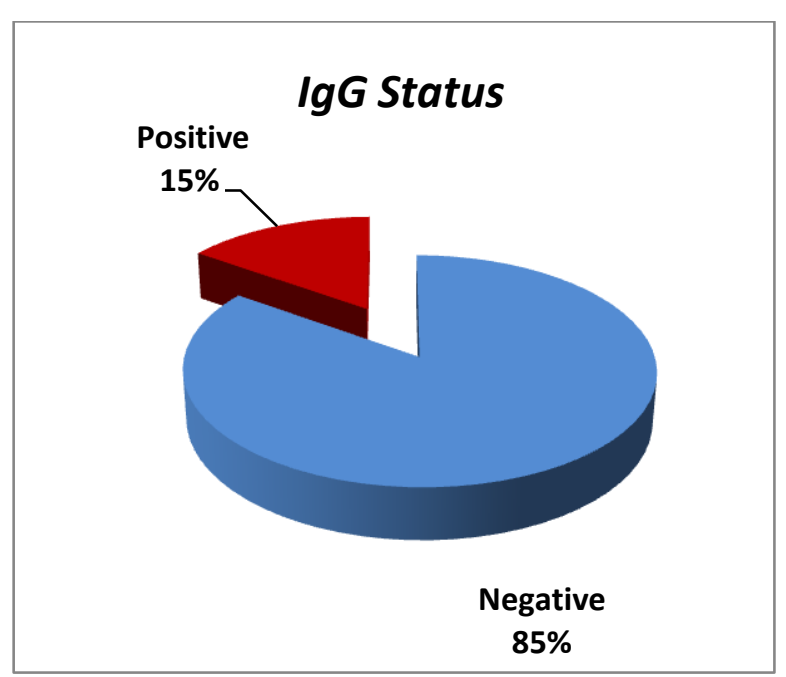

Figure 3.1: Results of ELISA for detection of antiHAV IgG antibodies.

In 270 subjects, $139(51.5 \%)$ were females and $131(48.5 \%)$ were males. Among the positive subjects, $20(48.78 \%)$ were females and $21(51.22 \%)$ were males. There was no significant difference in IgG antiHAV positivity between the two genders. This is similar to the studies published by Dhawan et al ${ }^{19}$, Mall et $a l^{12}$. These findings suggest that gender difference is not a risk factor for acquiring hepatitis A infection. 
Out of 270 subjects in the study, 175 (64.8\%) were in the age group of 18-25 years, 65 in the age group 26-32 years $(24.1 \%)$ and $30(11.1 \%)$ were in the age group 33-45 years. Among the 41 anti HAV IgG positive subjects, the prevalence of IgG anti HAV antibodies was maximum for age group 40-45 years (20\%) and the lowest prevalence was noted among subjects of 26-32 years (13.8\%)(Table 3.1). Though this age-wise difference in seroprevalence data was statistically insignificant, the overall decline in the seroprevalence should not be overlooked. This also reiterate the findings of Mall et $a l^{12}$ that an epidemiological transition has been observed about the HAV infections in India, from that of an hyperendemicity area to that of an intermediate endemicity area. He also noted a decline in HAV infection rate in children and increase in the number of susceptible adolescents and adults at risk of infection and clinical disease. Due to ethical issues those $<18$ years were not included in the study. This might have been one reason why the age wise difference in seroprevalence could not be proved.

Table 3.1: Description of subjects according to their age and IgG anti HAV antibody positivity

\begin{tabular}{|c|c|c|c|c|c|c|c|}
\hline \multirow{2}{*}{$\begin{array}{l}\text { Age } \\
\text { group } \\
\text { (years) }\end{array}$} & \multicolumn{2}{|c|}{$\begin{array}{l}\text { IgG anti HAV } \\
\text { positive }\end{array}$} & \multicolumn{2}{|c|}{$\begin{array}{l}\text { IgG anti HAV } \\
\text { negative }\end{array}$} & \multicolumn{2}{|c|}{ Total } & \multirow[t]{2}{*}{$\begin{array}{l}\text { Signific } \\
\text { ance }\end{array}$} \\
\hline & $\begin{array}{l}\text { Frequ } \\
\text { ency }\end{array}$ & $\begin{array}{l}\text { percen } \\
\text { tage }\end{array}$ & $\begin{array}{l}\text { Frequ } \\
\text { ency }\end{array}$ & $\begin{array}{l}\text { percen } \\
\text { tage }\end{array}$ & $\begin{array}{l}\text { Frequ } \\
\text { ency }\end{array}$ & $\begin{array}{l}\text { percen } \\
\text { tage }\end{array}$ & \\
\hline $18-25$ & 27 & 15.4 & 148 & 84.6 & 175 & 65 & $\begin{array}{l}\chi^{2}= \\
0.06\end{array}$ \\
\hline $26-32$ & 9 & 13.8 & 56 & 86.1 & 65 & 24 & $\mathrm{df}=1$ \\
\hline $33-39$ & 3 & 16.7 & 15 & 83.3 & 18 & 6.6 & \\
\hline $40-45$ & 2 & 20.0 & 10 & 83.3 & 12 & 4.4 & \\
\hline Total & 41 & 15.2 & 229 & 84.8 & 270 & 100 & \\
\hline
\end{tabular}

The subjects were also categorized on the basis of their socio-economic status according to modified Kuppuswamy scale. 9 of the subjects belonged to lower socio-economic class (3.3\%), 57 belonged to lower middle class $(21.1 \%), 199$ were from upper middle class $(73.7 \%)$ and five belonged to upper socio-economic class $(1.9 \%)$. The highest seroprevalence was found in lower middle class $(17.5 \%)$. The high prevalence in middle class when compared to other classes was found to be statistically significant $(\mathrm{p}<0.05)$ (Table 3.2).
Table 3.2: Description of subjects according to their socio-economic status and IgG anti-HAV antibody positivity

\begin{tabular}{|c|c|c|c|c|c|c|c|}
\hline \multirow{2}{*}{$\begin{array}{l}\text { SE } \\
\text { Status }\end{array}$} & \multicolumn{2}{|c|}{$\begin{array}{c}\text { IgG anti HAV } \\
\text { positive }\end{array}$} & \multicolumn{2}{|c|}{$\begin{array}{c}\text { IgG anti HAV } \\
\text { negative }\end{array}$} & \multicolumn{2}{|c|}{ Total } & \multirow[t]{3}{*}{$\begin{array}{l}\text { Signifi } \\
\text { cance }\end{array}$} \\
\hline & $\begin{array}{l}\text { Frequ } \\
\text { ency }\end{array}$ & $\begin{array}{l}\text { percen } \\
\text { tage }\end{array}$ & $\begin{array}{l}\text { Frequ } \\
\text { ency }\end{array}$ & $\begin{array}{c}\text { percen } \\
\text { tage }\end{array}$ & $\begin{array}{c}\text { Freque } \\
\text { ncy }\end{array}$ & $\begin{array}{l}\text { perce } \\
\text { ntage }\end{array}$ & \\
\hline Lower & 0 & 0 & 0 & 0 & 0 & 0 & \\
\hline $\begin{array}{l}\text { Upper } \\
\text { lower }\end{array}$ & 0 & 0 & 9 & 100 & 9 & 3.3 & $\begin{array}{c}\chi^{2}=9.5 \\
86\end{array}$ \\
\hline $\begin{array}{l}\text { Lower } \\
\text { middle }\end{array}$ & 10 & 17.5 & 47 & 82.5 & 57 & 21.1 & $\mathrm{df}=4$ \\
\hline $\begin{array}{l}\text { Upper } \\
\text { middle }\end{array}$ & 31 & 15.6 & 168 & 84.4 & 199 & 73.7 & $\mathrm{p}<0.05$ \\
\hline Upper & 0 & 0 & 5 & 100 & 5 & 1.9 & \\
\hline Total & 41 & 15.2 & 229 & 84.8 & 270 & 100 & \\
\hline
\end{tabular}

This was similar to the data published by Mall et $\mathrm{al}^{12}$ where the seropositivity was lower in high income groups (49\%; 95\% CI 34-64\%) than in lower income group (88\%; 95\% CI 76-96\%) in children from Calcutta. In children from Patna, the seropositivity were $69 \%$ (95\% CI 55-81\%) in high income group and $85 \%$ (95\% CI 4-93\%) in low income group. However, some other studies from India by Das et $a l^{20}$, Batra et $a l^{21}$, Joshi ${ }^{22}$ et al do not show significant differences between the seroprevalence data from different socio economic classes.

$210(77.8 \%)$ subjects obtained their drinking water from shallow well, 17 subjects $(6.3 \%)$ used water from tube well and 43 subjects $(15.9 \%)$ depended on municipal water supply for drinking purposes. The highest prevalence of anti-HAV IgG antibodies was seen in subjects depending on Municipal water supply as the source of drinking water(23.3\%), followed by those depending on shallow well $(15.3 \%)$ and the lowest seroprevalence was noted among those using tube well water (5.9\%). This association was however statistically insignificant (Fig 3.2). This is consistent with data published by Dutta $e t a l^{23}$. In contrast to this finding, a study by Mall et $a l^{12}$ in 5 centers throughout India showed that the seroprevalence was higher $(\mathrm{p}<0.001)$ in those using municipal water supply $(73.2 \%)$ than in those using water from wells $(58.8 \%)$. Another study by Chitambar et al ${ }^{24}$ from West India showed a significant decline in seroprevalence of anti HAV 
antibodies in those awailing municipal water supply (88.6\%) compared to those who used water from wells for drinking purpose $(97.52 \%, \mathrm{p}<0.05)$. The difference in all these studies might have arised due to the differences in pretreatment of drinking water provided through Municipal supply or in wells.

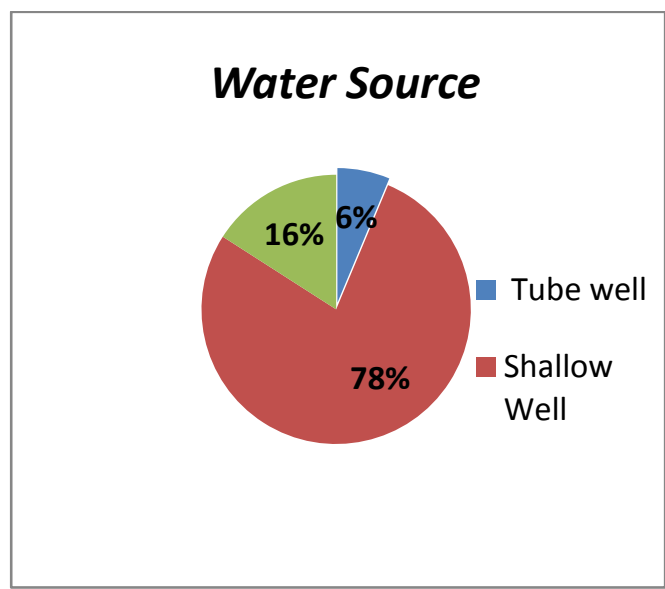

Figure 3.2: Source of drinking water of the subjects.

Subjects were also studied on the basis of the method used for purification of drinking water. 175 of the study subjects $(64.8 \%)$ were in the habit of boiling water prior to drinking, 26 study subjects $(9.7 \%)$ used water filters and $69(25.5 \%)$ admitted that no method of water purification was done. Highest seroprevalence was found in persons who do not use a method of water purification (18.8\%), followed by subjects who used to boil drinking water(14.3\%) and the lowest prevalence was found in water-filter users. (Fig 3.3). However this association was found to be statistically insignificant. But this study was a one point analysis and so the total duration of these habits could not be studied. This may be the reason why the association between seroprevalence and method of water purification could not be established. Similarly, a study by Dhawan et $a l^{19}$ could not establish a relationship between method of water purification employed and seropositivity to anti HAV antibodies. In contrast, study by Mall et l $^{12}$ showed that antiHAV seropositivity was significantly lower if water was purified prior to consumption irrespective of the water source.

\section{Methods of Water Purification}

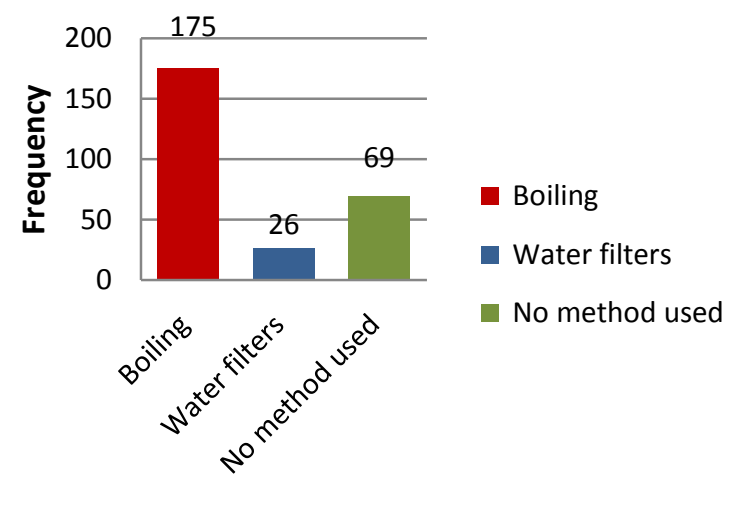

Figure 3.3: Methods employed for the purification of drinking water.

In this study, among the 270 subjects, 247 (91.5\%) had past history of jaundice. No significant statistical association between past history of jaundice and IgG antiHAV positivity was found out. This finding may be due to the fact that majority of the infections in childhood are subclinical ${ }^{25}$.

None of the subjects were vaccinated for Hepatitis A. Subjects were also interviewed about the awareness about the mode of spread of hepatitis A. Though majority of the subjects were highly educated, $49.3 \%$ of the subjects were unaware about the mode of infection or the importance of safe water and personal hygiene in prevention of the disease. This finding stresses the importance of health education in general population prior to any intervention like vaccination in preventing hepatitis A infection.

\section{Conclusions}

Out of the 270 study subjects, $41(15.2 \%)$ were found to be positive for IgG anti HAV antibodies. A significant statistical association with socioeconomic status and $\mathrm{IgG}$ positivity was found out.

As the present study points out a declining seroprevalence of hepatitis A virus infection in the population, further seroprevalence studies have to be carried out in younger age group $<18$ years to confirm the declining seroprevalence rates. A costbenefit analysis study has to be performed to assess the need of mass vaccination of school children to prevent outbreaks. Further studies to determine the 
prevalent genotype in the area should be carried out. As the awareness about the disease was only present for $50.7 \%$ of the study population, health education with emphasis on personal hygiene has to be implemented to prevent further outbreaks.

\section{Acknowledgement}

The authors would like to acknowledge the medical students of this institution and staff of Sneha lab and blood bank for their co-operation in sample collection.

\section{Funding: No funding sources}

Ethical approval: The study was approved by the Institutional ethical committee.

Conflict of interest: None declared

\section{References}

1. Bell BP, Feinstone SM. Hepatitis A vaccine. Virus description. In: Plotkin S, ed. Vaccines, 4th ed. Philadelphia, PA: Saunders, 2004: 269-97.

2. Hepatitis A (Fact sheet $\mathrm{N}^{0} 328$ ). World Health Organization, Geneva, Switzerland, 2017 [cited October 2017]. Available from: http://www.who.int/mediacentre/factsheets/f s328/en/

3. McCaustland KA, Bond WW, Bradley DW, Ebert JW, Maynard JE. 1982. Survival of hepatitis A virus in feces after drying and storage for 1 month. J. Clin. Microbiol. 16:957-58.

4. Lemon SM. The natural history of hepatitis A; the potential for transmission by blood or blood products. Vox Sang 1994; 67(suppl 4):19-23.

5. Bell BP, Shapiro CN, Alter MJ, et al. The diverse patterns of hepatitis A epidemiology in the United States-implications for vaccination strategies. J Infect Dis. 1998; 178: 1579-84.

6. Gupta E, Ballani N. State of the globe: Hepatitis A virus return of a water devil. J Global Infect Dis 2014;6:578.
7. Wasley A, Fiore A, Bell BP. Hepatitis A in the era of vaccination. Epidemiol Rev. 2006;28:101-11.

8. Averhoff F, Khudyakov Y, Bell B.P. Hepatitis A Virus. In: Bennet JE, Dolin R, Blaser MJ, editors. Mandell, Douglas and Bennet's Principles and Practice of Infectious Diseases. $8^{\text {th }}$ ed . Philadelphia: Saunders Elsevier; c2015. Chapter 176. p.2988-91.

9. Werzberger A, Mensch B, Kuter B, Brown L, Lewis J, Sitrin R, et al. A controlled trial of a formalin-inactivated hepatitis A vaccine in healthy children. N Engl J Med 1992; 327:453-57.

10. Innis BL, Snitbhan R, Kunasol P, Laorakpongse T, Poopatanakool W, Kozik $\mathrm{CA}$, et al. Protection against hepatitis A by an inactivated vaccine. JAMA 1994; 271:1328-34.

11. Midthun K, Ellerbeck E, Gershman K, Calandra G, Krah D, McCaughtry M, et al. Safety and immunogenicity of a live attenuated hepatitis A virus vaccine in seronegative volunteers. J Infect Dis 1991; 163:735-39.

12. Mall ML, Rai RR, Philip M, Naik G, Parekh $\mathrm{P}$, Bhawnani SC, et al. Seroepidemiology of hepatitis A infection in India: changing patterns. Indian J Gastroenterol 2001; 20: 132-35.

13. Arankalle VA, Sarada Devi KL, Lole KS, Shenoy KT, Verma V, Haneephabi M. Molecular characterization of hepatitis A virus from a large outbreak from Kerala, India. Indian J Med Res. 2006; 123:760-69.

14. Sebastian B, Mathai S, Mathew G, Ouseph M, Balakrishnan P. An outbreak of hepatitis A in central Kerala Clinical Profile. Indian J Gastroenterol. 1998; 17;10.

15. Arankalle VA, Sarada Devi KL, Lole KS, Shenoy KT, Verma V, Haneephabi M. Molecular characterization of hepatitis A virus from a large outbreak from Kerala, India. Indian J Med Res. 2006; 123:760-69. 
16. Rakesh PS, Sherin D, Sankar H, Shaji M, Subhagan S, Salila S. Investigating a community wide outbreak of hepatitis $A$ in India. J Global Infect Dis. 2014; 6:59-64.

17. Mathur P, Arora N K. Epidemiological transition of hepatitis A in India: Issues for vaccination in developing countries. Indian $\mathbf{J}$ Med Res. 2008; 128:699-704.

18. Mathew P, Bobba R, Zacharias P. Hepatitis A seroprevalence in Kerala. Indian $J$ Gastroenterol 1998; 17: S71-72.

19. Dhawan PS, Shah SS, Alvares JF, Kher A, Shankaran K, Kondoth PW, et al. Seroprevalence of hepatitis A virus in Mumbai and immunogenicity and safety of hepatitis A vaccine. Indian J Gastroenterol 1998; 17: 16-18.

20. Das K, Kar P, Chakraborty A, Gupta S, Das $B C$. Is vaccination program against hepatitis A needed in India? Indian $\mathrm{J}$ Gastroenterol 1998; $17: 158$.

21. Batra Y, Bhatkal B, Ojha B, Kaur K, Saraya A, Panda SK, et al. Vaccination against hepatitis A virus may not be required for school children in northern India: results of a seroepidemiological survey. Bull World Health Organ 2002; $80: 728-31$

22. Joshi N, Nagarjuna KYR, Kumar A. Age related seroprevalence of antibodies to hepatitis A virus in Hyderabad, India. Trop Gastroenterol 2000; 21: 63-65.

23. Dutta AK, Aggarwal A, Kapoor AK, Ray GN, Batra S. Seroepidemiology of hepatitis a in Delhi. Indian J Pediatr 2000; 67:77-79.

24. Chitambar SD, Chadha MS, Joshi MS, Arankalle VA. Prevalence of hepatitis A antibodies in Western Indian population: a changing pattern. Southeast Asian J Trop Med Public Health 1999,30:273-76

25. Jacobsen KH, Wiersma ST. Hepatitis A virus seroprevalence by age and world region, 1990 and 2005. Vaccine 28 (2010) 6653-57. 